\title{
THE CONSTITUTIONAL VALIDITY OF DECLARATIONS OF INCOMPATIBILITY IN AUSTRALIAN CHARTERS OF RIGHTS
}

\author{
DOMINIQUE DALLA-POZZA* AND GEORGE WILLIAMS *
}

[New Australian human rights legislation has created novel 'dialogues' between different arms of government. In Victoria and the ACT courts have been empowered to make declarations of incompatibility to the Attorney-General regarding the human rights acts and other legislation. This article examines the Constitutional implications for a similar mechanism in a proposed Commonwealth Human Rights Act]

\section{INTRODUCTION}

The Australian Capital Territory was the first Australian jurisdiction to enact a Bill or Charter of Human Rights with its Human Rights Act 2004 (the ACT Human Rights Act). Victoria became the first Australian State to do so when it passed the Charter of Human Rights and Responsibilities Act 2006 (the Victorian Charter). These laws have given fresh impetus to attempts to enact a Charter at the national level. New Matilda, an independent online magazine and policy portal, has drafted a Human Rights Bill (the New Matilda Bill) and has campaigned to have it introduced into the Federal Parliament. ${ }^{1}$

\footnotetext{
* PhD Candidate, Gilbert + Tobin Centre of Public Law, Faculty of Law, University of New South Wales.

** Anthony Mason Professor and Director, Gilbert + Tobin Centre of Public Law, Faculty of Law, University of New South Wales; Barrister, New South Wales Bar. We thank Anna Saulwick and Shreeya Muthusamy for their research assistance and the anonymous referee.
}

1 See www.humanrightsact.com.au (4 December 2006). 


\section{DEAKIN LAW REVIEW}

VOLUME 12 No 1

Both the ACT and Victorian Acts were the subject of extensive community consultation. ${ }^{2}$ New Matilda has also invited comment from members of the public. ${ }^{3}$ These processes have produced legislation that is not based on the United States Bill of Rights, in which the Supreme Court can strike down inconsistent legislation. The Australian laws contain no such power, and are

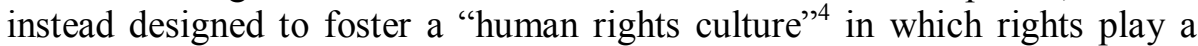
prominent role in the formulation, interpretation and review of laws and policies.

Each of the Australian laws contains mechanisms to protect human rights through a form of "dialogue" between the arms of government. Whether or not dialogue $e^{5}$ is the correct word for what the laws achieve, it is clear that they create new and innovative forms of deliberation and interaction for law, policy and politics as they relate to human rights. This interaction is focused upon the consistency of laws with the rights included in the human rights instrument. ${ }^{6}$ Under the ACT Human Rights Act courts have the power

2 ACT Bill of Rights Consultative Committee, Legislative Assembly of the Australian Capital Territory, Towards an ACT Human Rights Act (2003), 13; Human Rights Consultation Committee, Rights, Responsibility and Respect: The Report of the Human Rights Consultation Committee (2005).

3 See

www.humanrightsact.com.au/index.php?option $=$ com_content\&task $=$ view\&id=63\&It emid=33 (1 November 2006).

4 Elizabeth Kelly, Acting CEO, ACT Department of Justice and Community Safety, "How Does the ACT Human Rights Act Protect Human Rights?" (Paper presented at the Conference on Australia's First Bill of Rights, Australian National University, Canberra, 1 July 2004) 1, Human Rights Consultation Committee, above n 2, 92.

5 For the initial use of this now widely used the term, see Peter W Hogg and Allison A Bushell "The Charter Dialogue between Courts and Legislatures" (1997) 35 Osgoode Hall Law Journal 75. This use of the "dialogue" metaphor has provoked intense debate in Canada. See Christopher P Manfredi and James B Kelly "Six Degrees of Dialogue: A Response to Hogg and Bushell" (1999) 37 Osgoode Hall Law Journal 513 and the further response by Peter W Hogg and Allison A Thornton "Reply to 'Six Degrees of Dialogue"” (1999) 37 Osgoode Hall Law Journal 529. Amongst the now large volume of literature, see also Kent Roach, The Supreme Court on Trial: Judicial Activism or Democratic Dialogue (2001) and for an Australian treatment Leighton McDonald, "Rights, "Dialogue" and Democratic Objections to Judicial Review" (2004) 32 Federal Law Review 1.

6 ACT Bill of Rights Consultative Committee, above n 2, 61-68. Human Rights Consultation Committee, Parliament of Victoria, above n 2, 66-68 and New Matilda, "Human Rights Act for Australia"; Explanatory Information (2006) A Human Rights Act for Australia 
to make a "declaration of incompatibility" in respect of a Territory law. ${ }^{7}$ The New Matilda Bill allows the judiciary to make a similarly named declaration, ${ }^{8}$ while the Victorian Charter empowers Victorian courts to issue a "declaration of inconsistent interpretation" that operates in the same manner."

These declaratory mechanisms alert the legislature and the executive that a court has identified an incompatibility between a protected human right and another statute. In each case the declaration ${ }^{10}$ is accompanied by an obligation on the Attorney-General to prepare a response and to ensure that the declaration and the response are presented to parliament. ${ }^{11}$ A dialogue is thus created between the judiciary, executive and legislature that provides a framework in which to consider the implications, justifications and possibilities of reform for the law in question. A critical feature of this dialogue is that it maintains the final say of the legislature, preserving parliamentary sovereignty.

In this article we examine the constitutional validity of the power to make declarations of incompatibility in the ACT Human Rights Act, Victorian Charter and New Matilda Bill. While the last has not been introduced into the federal Parliament, ${ }^{12}$ it does provide a useful basis from which to analyse the issues at the federal level. Overall, we examine the impact that the differing federal, state and territory constitutional frameworks have on the issue of

www.newmatilda.com/admin/imageLibrary/images/HRA_explanatory_info\%20AU GUST\%2020061PGr3VU321J2.doc at 30 October 2006, $\overline{4}$

7 See s 32 of the Human Rights Act 2004 (ACT) which is extracted below. Hereafter this will be cited as the ACT Human Rights Act.

8 See s 51 of the New Matilda Human Rights Bill 2006 which is extracted below. The complete bill is available at www.humanrightsact.com.au/index.php?option $=$ com_content\&task=blogcategory\&i $\mathrm{d}=20$ \&Itemid $=34$. Hereafter this will be cited as the New Matilda Bill.

9 See s 36 of the Charter of Rights and Responsibilities Act 2006 (Vic) which is extracted below. Hereafter this will be cited as the Victorian Charter.

10 Hereafter all three declaration mechanisms will be referred to as "Declarations of Incompatibility".

11 See s 33 of the ACT Human Rights Act, s 37 of the Victorian Charter, s 51 of the New Matilda Bill.

12 See New Matilda, "A Human Rights Act for Australia: Campaign Overview www.humanrightsact.com.au/index.php?option $=$ com_content\&task=blogcategory\&i $\mathrm{d}=19 \&$ Itemid $=36$ at 13 June 2007. 
4 Deakin LaW ReVIEW

VOLUME 12 No 1

constitutional validity. To date, a court has yet to consider the validity of the $\mathrm{ACT}$ and Victorian mechanisms. ${ }^{13}$

In Part II we set out the declaration mechanisms from each instrument. We then determine in Part III whether empowering a court to make such a declaration breaches the separation of judicial power mandated by Chapter III of the Australian Constitution. Initially, we examine whether making a declaration of incompatibility is an exercise of judicial power. While we conclude that the mechanisms do involve an exercise of judicial power and thus are constitutionally valid, this cannot be stated with certainty. Accordingly in Part IV we examine the constitutional consequences for the alternative that the making of such declarations is an exercise of non-judicial power.

\section{The Declaration Mechanisms}

The ACT Human Rights Act, Victorian Charter and New Matilda Bill each contain declaration mechanisms that are alike in structure and operation. In the ACT Human Rights Act, s 32 provides:

(1) This section applies if-

(a) a proceeding is being heard by the Supreme Court; and

(b) an issue arises in the proceeding about whether a Territory law is consistent with a human right.

(2) If the Supreme Court is satisfied that the Territory law is not consistent with the human right, the court may declare that the law is not consistent with the human right (the declaration of incompatibility).

(3) The declaration of incompatibility does not affect-

(a) the validity, operation or enforcement of the law; or

(b) the rights or obligations of anyone.

13 A search of the ACT Human Rights Act Database indicates that as at 21 June 2007 only two cases have considered the declaration of incompatibility mechanism, and the constitutionality of the mechanism was not considered in either. See Australian National University "ACT Human Rights Act Case Database" acthra.anu.edu.au/cases/index.php?form_action=search\&list_all=\&page_num=\&key 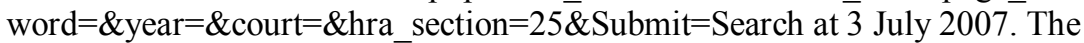 declaration mechanism in the Victorian Charter does not come into operation until 1 January 2008, see s 2 of the Victorian Charter. 
(4) The registrar of the Supreme Court must promptly give a copy of the declaration of incompatibility to the AttorneyGeneral.

A second part of the mechanism in s 33 sets out how parliament is required to respond:

(1) This section applies if the Attorney-General receives a copy of a declaration of incompatibility.

(2) The Attorney-General must present a copy of the declaration of incompatibility to the Legislative Assembly within 6 sitting days after the day the Attorney-General receives the copy.

(3) The Attorney-General must prepare a written response to the declaration of incompatibility and present it to the Legislative Assembly not later than 6 months after the day the copy of the declaration is presented to the Legislative Assembly.

While the Victorian Charter refers to "declarations of inconsistent interpretation" rather than "declarations of incompatibility", the similarities between the Victorian and ACT legislation are clear. Section 36 of the Victorian Charter states:

(1) This section applies if -

(a) in a Supreme Court proceeding a question of law arises that relates to the application of this Charter or a question arises with respect to the interpretation of a statutory provision in accordance with this Charter; or

(b) the Supreme Court has had a question referred to it under section 33; or

(c) an appeal before the Court of Appeal relates to a question of a kind referred to in paragraph (a).

(2) Subject to any relevant override declaration, if in a proceeding the Supreme Court is of the opinion that a statutory provision cannot be interpreted consistently with a human right, the Court may make a declaration to that effect in accordance with this section.

(3) If the Supreme Court is considering making a declaration of inconsistent interpretation, it must ensure that notice in the 
prescribed form of that fact is given to the Attorney-General and the Commission.

(4) The Supreme Court must not make a declaration of inconsistent interpretation unless the Court is satisfied that-

(a) notice in the prescribed form has been given to the Attorney-General and the Commission under subsection (3); and

(b) a reasonable opportunity has been given to the Attorney-General and the Commission to intervene in the proceeding or to make submissions in respect of the proposed declaration of inconsistent interpretation.

A declaration of inconsistent interpretation does not-

(a) affect in any way the validity, operation or enforcement of the statutory provision in respect of which the declaration was made; or

(b) create in any person any legal right or give rise to any civil cause of action.

The Supreme Court must cause a copy of a declaration of inconsistent interpretation to be given to the Attorney-General-

(a) if the period provided for the lodging of an appeal in respect of the proceeding in which the declaration was made has ended without such an appeal having been lodged, within 7 days after the end of that period; or

(b) if on appeal the declaration is upheld, within 7 days after any appeal has been finalised.

The Attorney-General must, as soon as reasonably practicable, give a copy of a declaration of inconsistent interpretation received under subsection (6) to the Minister administering the statutory provision in respect of which the declaration was made, unless the relevant Minister is the AttorneyGeneral.

The obligations that result from a declaration are set out in s 37 :

Within 6 months after receiving a declaration of inconsistent interpretation, the Minister administering the statutory provision in respect of which the declaration was made must-

(a) prepare a written response to the declaration; and 
(b) cause a copy of the declaration and of his or her response to it to be-

(i) laid before each House of Parliament; and

(ii) published in the Government Gazette.

The mechanism in the New Matilda Bill adopts the same formula. Section 51 states:

(1) If a Court is satisfied that a provision of primary legislation is incompatible with a right or freedom set down in this Act, it may make a declaration of incompatibility.

(2) If a Court is satisfied that a provision of subordinate legislation, made in the exercise of a power conferred by primary legislation, is incompatible with a right or freedom set down in this Act, and that the primary legislation concerned prevents removal of the incompatibility, it may make a declaration of that incompatibility.

(3) If a Court is satisfied that a provision of subordinate legislation, made in the exercise of a power conferred by primary legislation, is incompatible with a right or freedom set down in this Act, and that the primary legislation concerned does not prevent removal of the incompatibility, it may invalidate that provision.

(4) A declaration under sub-sections (1) and (2) (a declaration of incompatibility)

(a) does not affect the validity, continuing operation or enforcement of the provision in respect of which it is given; and

(b) is not binding on the parties to the proceedings in which it is made.

(5) A Court must transmit a copy of any declaration of incompatibility to the Attorney-General.

(6) This section applies when a court is exercising jurisdiction in any cause or matter pending before it.

Section 52 then follows a familiar pattern:

(1) This section applies if the Attorney-General receives a copy of a declaration of incompatibility.

(2) The Attorney-General must present a copy of the declaration of incompatibility to the House of Representatives within 15 
8 Deakin LaW ReVIeW

VOLUME 12 No 1

sitting days after the day the Attorney-General receives the copy.

(3) The Attorney-General must prepare a written response to the declaration of incompatibility indicating what action if any is proposed in relation to it and the reasons for that action or non-action, and present it to the House of Representatives not later than 6 months after the day the copy of the declaration is presented to the House of Representatives.

These mechanisms are derived from like statutes in New Zealand and the United Kingdom. The New Zealand Bill of Rights Act 1990 (NZ) does not make express reference to declarations of incompatibility. The procedure was instead "read into" the statute by the New Zealand Court of Appeal in Moonen v Film and Literature Board of Review. ${ }^{14}$ In 2001 a declaration of incompatibility mechanism was inserted by legislative amendment into the Human Rights Act 1993 (NZ). ${ }^{15}$

The mechanism can also be found in s 4 of the Human Rights Act 1998 (UK). Under the UK legislation a declaration of incompatibility triggers a "fasttrack" amendment process whereby the responsible Minister may make amendments to the Act in order to remove the inconsistency. It has not been suggested in the United Kingdom that this mechanism is illegitimate or inappropriate in the functions it confers upon courts. Instead it is often regarded as a model of legislative drafting in balancing the powers of the legislative and judicial arms of government. Judges such as Lord Steyn and Lord Rodger of Earlsferry have, respectively, described the Human Rights Act as "carefully and subtly drafted"16 and even "beautifully drafted". ${ }^{17}$ However, these endorsements are of little assistance in determining whether the declaration mechanisms in Australia are constitutionally valid. Unlike Australia, the United Kingdom lacks a separation of judicial power brought about by a written constitution.

14 [2000] 2 NZLR 9.

15 Sections 92J and 92K of the Human Rights Act 1993 (NZ).

16 R v DPP; Ex parte Kebeline [1999] 4 All ER 801, 831 per Lord Steyn.

17 Wilson v First County Trust Ltd [2003] 4 All ER 97, 148 per Lord Rodger of Earlsferry. 


\section{AN EXERCISE OF JUDICIAL POWER?}

The separation of judicial power brought about by Chapter III of the Constitution entails two consequences. As Dixon $\mathrm{J}$ recognised in Victorian Stevedoring and General Contracting Co Pty Ltd and Meakes v Dignan, ${ }^{18}$ "the Parliament is restrained both from reposing any power essentially judicial in any other organ or body, and from reposing any other than that judicial power in such tribunals". Hence, the Constitution requires that:

1. only Chapter III courts (that is, courts created under s 71 of the Constitution) be conferred with judicial power; and

2. Chapter III courts cannot be conferred with power other than judicial power, except where such other power is ancillary or incidental to the exercise of judicial power.

The key to both is the definition of judicial power.

While there have been many attempts to define judicial power, the High Court has not provided a definitive list of its content or characteristics. The difficulty in formulating a definition has often been acknowledged. In Tasmanian Breweries, Windeyer J observed that "the concept seems ... to defy, perhaps it were better to say transcend, purely abstract conceptual analysis". ${ }^{19}$ In $R v$ Quinn; Ex parte Consolidated Foods Corporation ${ }^{20}$ Aickin $J$ concluded that "in substance all that the courts have been able to say towards a definition has been the formulation of negative propositions by which it has been said that no one of a list of factors is itself conclusive and perhaps the presence of all is not conclusive". More recently, the Court has suggested that "framing a definition of judicial power that is at once exclusive and exhaustive" may be an "impossibility". ${ }^{21}$

In Brandy v Human Rights and Equal Opportunities Commission, Deane, Dawson, Gaudron and McHugh JJ explained that:

[d]ifficulty arises in attempting to formulate a comprehensive definition of judicial power not so much because it consists of a number of factors as because the combination [of factors] is not always the same. It is hard to point to any essential or constant

18 (1931) 46 CLR 73, 98.

19 R v Trade Practices Tribunal; Ex parte Tasmanian Breweries Pty Ltd (1970) 123

CLR 361, 394.

20 (1977) 138 CLR 1, 15.

21 Precision Data Holdings Ltd v Wills (1991) 173 CLR 167, 188 per Mason CJ, Brennan, Deane, Dawson, Toohey, Gaudron and McHugh JJ. 
10 Deakin LaW ReVIEW

VOLUME 12 No 1

characteristic. Moreover, there are functions which, when performed by a court, constitute the exercise of judicial power but, when performed by some other body, do not. ${ }^{22}$

Over time, the Court has articulated a series of indicia of judicial power. As the passage from Brandy suggests, none of these indicia are by themselves decisive. Whether a power can be said to be "judicial" depends upon the indicia present in the power being "weighed" against those which are absent, or against other countervailing indicia. The traditional starting point in lists of these indicia is the view offered by Griffiths CJ in Huddart, Parker \& Co Pty Ltd v Moorehead: ${ }^{23}$

I am of opinion that the words "judicial power" as used in sec 71 of the Constitution mean the power which every sovereign authority must of necessity have to decide controversies between its subjects, or between itself and its subjects, whether the rights relate to life, liberty or property. The exercise of this power does not begin until some tribunal which has power to give a binding and authoritative decision (whether subject to appeal or not) is called upon to take action.

Justice Kitto further stated in Tasmanian Breweries: ${ }^{24}$

Thus a judicial power involves, as a general rule, a decision settling for the future, as between defined persons or classes of persons, a question as to the existence of a right or obligation, so that an exercise of the power creates a new charter by reference to which that question is in future to be decided as between those persons or classes of persons. In other words, the process to be followed must generally be an inquiry concerning the law as it is and the facts as they are, followed by an application of the law as determined to the facts as determined; and the end to be reached must be an act which, so long as it stands, entitles and obliges the persons between whom it intervenes, to observance of the rights and obligations that the application of law to facts has shown to exist.

22 Brandy v Human Rights and Equal Opportunity Commission (1995) 183 CLR $245,267$.

23 (1909) 8 CLR 330, 357.

24 R v Trade Practices Tribunal; Ex parte Tasmanian Breweries Pty Ltd (1970) 123

CLR 361,374. 
In Brandy the majority affirmed that judicial power operates by making decisions "according to law ... by the application of a pre-existing standard rather than by the formulation of policy or the exercise of an administrative discretion". In the same case the High Court also identified the "enforceability of decisions" as a critical indicia of judicial power in situations where the characterisation of a function "is otherwise equivocal". ${ }^{25}$

This approach to defining "judicial power" has been praised by Lacey for rejecting a "formalistic approach... and focusing instead on the manner in which judicial power is exercised." 26 The lack of precision certainly allows the concept to be applied flexibly, if unpredictably. In the absence of a High Court precedent addressed to the issue, this means that it cannot be said with certainty whether the declaration of incompatibility mechanisms in the $A C T$ Human Rights Act, Victorian Charter or New Matilda Bill is an exercise of judicial power.

We address this issue by going back to first principles and the indicia of judicial power. At the first stage, we examine the extent to which the declaration mechanism exhibits the indicia of judicial power. At the second stage, we ask whether the declarations can be distinguished from processes which the court has already identified as being beyond the ambit of judicial power.

\section{A Using Legal Standards to Resolve a Controversy?}

One indication of judicial power is that it is a power that requires the use of legal standards, as opposed to policy criteria, in determining a dispute. The ACT Human Rights Act, the Victorian Charter and the New Matilda Bill have all been drafted to ensure that this is the case. Section 32(1) of the $A C T$ Human Rights Act provides that a declaration of incompatibility can be made if "(a) a proceeding is being heard by the Supreme Court; and (b) an issue arises in the proceeding about whether a Territory law is consistent with a human right." Thus the ACT legislation makes it clear that a declaration can only be made in the context of an existing controversy between parties who

25 Brandy v Human Rights and Equal Opportunity Commission (1995) 183 CLR 245, 268 per Deane, Dawson, Gaudron and McHugh JJ. See also Helen Irving "Advisory Opinions, The Rule of Law, and the Separation of Powers" (2004) 4 Macquarie Law Journal 105, 111.

26 Wendy Lacey, "Inherent Jurisdiction, Judicial Power and Implied Guarantees Under Chapter III of the Constitution" (2003) 31 Federal Law Review 57, 73. 
12 DEAKIN LAW REVIEW

VOLUME 12 No 1

are seeking to have their rights and liabilities determined. The legislation also sets out the defined legal standards which courts are to use to determine whether to issue a declaration. Section 32(2), states that if it "is satisfied that the Territory law is not consistent with the human right, the court may declare that the law is not consistent with the human right", and s 5 establishes that "human right" refers to one of the "civil and political rights in part 3" of the Act. Hence, a declaration of incompatibility is a determination of the consistency of an existing law as against one or more of these specific legal criteria.

The Victorian Charter expands the circumstances in which the Supreme Court might be asked to use the declaration of inconsistency mechanism. Section 36(1)(a) is analogous to the ACT Human Rights Act provision. It specifies that such a declaration may be made if "a question of law arises that relates to the application of this Charter or... to the interpretation of a statutory provision in accordance with this Charter" in proceedings before the Supreme Court of Victoria. A declaration can also be made if the Supreme Court has had a question referred to it under s 33 of the Victorian Charter. This section envisages a scenario where the Supreme Court will be able to hear a question which originated in existing proceedings "before a court or tribunal, a question of law ... that relates to the application of ... [the] Charter", or the way in which statutes might be interpreted in accordance with the Charter. Nonetheless, a request for a declaration in Victoria will still only arise in a situation where an underlying controversy between two parties already exists. In terms of the legal standards the court is to use to determine whether a declaration should be issued, the Victorian Charter replicates the ACT Human Rights Acts reference to specific legal criteria: s 3 of the Charter explains that "Human Rights" refers to the "civil and political rights set out in Part 2".

In the New Matilda Bill "Human Rights" are defined in s 6 as "the civil, political, economic, social and cultural rights set down in part 3". Thus this legislative proposal also sets up specific legal criteria by which compatibility with human rights can be judged. However, as originally drafted, the declaration of incompatibility formula adopted in the New Matilda Bill did not contain a requirement that such declarations could only be made in the context of an existing proceeding. This would have been a significant problem, given that judicial power can only be used where there is a controversy between two parties. This has been rectified in the final version of the proposal launched in August 2006. The Bill now contains s 51(6), which indicates a court has the power to make a declaration of incompatibility "when a court is exercising jurisdiction in any cause or matter 
pending before it". This ensures that a declaration could only be issued in the context of an existing controversy between parties.

It is also possible to argue that issuing a declaration resolves the controversy between the parties. As such the making of a declaration can be distinguished from the situation in Solomons $v$ District Court of New South Wales. ${ }^{27}$ That case involved a costs certificate that could be issued by a court under the Costs in Criminal Cases Act 1967 (NSW) to a person who had been acquitted of an offence. A person who received the certificate was entitled to apply to the Under-Secretary of the NSW Attorney-General's Department to have their costs of the proceedings paid for by the State. The difficulty faced by Mr Solomon was that he was charged with a federal rather than NSW offence. Gleeson CJ, Gaudron, Gummow, Hayne and Callinan JJ found that if the District Court issued such a certificate it would be exercising "power not provided by Chapter III of the Constitution [because the certificate]... would be productive of a futility, not the resolution of any claim or controversy". ${ }^{28}$ An application for a certificate would not have concluded any controversy given the absence of a corresponding costs recovery scheme at the federal level. By contrast, the ACT Human Rights Act, Victorian Charter and New Matilda Bill only place obligations on the Attorney-General in their respective jurisdiction. For example, a declaration under the ACT Human Rights Act only places obligations on the Attorney-General of the ACT.

\section{B Binding and Authoritative?}

Each legislative scheme provides that declaring that a particular law is incompatible does not render that law invalid or affect the enforcement of the law. ${ }^{29}$ The ACT legislation even makes explicit that the making of such a declaration does not affect "the rights or obligations of anyone". ${ }^{30}$ The Victorian Charter contains a slightly different formulation, indicating that a "declaration of inconsistent interpretation does not...create in any person any legal right or give rise to any civil cause of action". "The New Matilda Bill states that a declaration of incompatibility "is not binding on the parties to the

27 (2002) 211 CLR 119.

28 Solomons v District Court of NSW (2002) 211 CLR 119, 136.

29 Section 32(3)(a) of the ACT Human Rights Act, s 36(5)(a) of the Victorian

Charter and s 51(4)(a) of the New Matilda Bill.

30 Section 32(3)(b) of the ACT Human Rights Act.

31 Section 36(5)(b) of the Victorian Charter. 
14 DeAKIN LAW REVIEW

VOLUME 12 No 1

proceedings in which it is made" $" 32$. These limits preserve parliamentary sovereignty by signalling that while the judiciary has an important role in protecting rights, it is parliament that has the final responsibility to determine how any tension between rights protection and other legislation is to be resolved. $^{33}$

Despite this, the indicia of judicial power can be found in the declaration mechanisms. First, it is important to recognise that declarations generally "are statutory rather than equitable remedies". ${ }^{44}$ This suggests that when a parliament bestows the power to make declarations on a court such declarations are intended to be statements of law. Indeed, that declarations are statements of law arguably lies behind the High Court's recognition that a court's power to make declarations "is confined by the considerations which mark out the boundaries of judicial power., 35

Second, each of the mechanisms makes clear that binding obligations do flow once courts have declared that an incompatibility or inconsistency exists. Section 32(4) of the ACT Human Rights Act states that the registrar of the Supreme Court "must promptly give a copy of the declaration of incompatibility to the Attorney-General", while s 33 imposes two duties upon the Attorney-General. The Attorney-General "must", under s 33(2), "present a copy of the declaration of incompatibility to the Legislative Assembly within 6 sitting days after the day the Attorney-General receives the copy" and, under s 33(3), "prepare a written response to the declaration of incompatibility and present it to the Legislative Assembly not later than 6 months after the day the copy of the declaration is presented to the Legislative Assembly".

These obligations are echoed in the Victorian Charter. Section 36(6) specifies that the Supreme Court must ensure that the Attorney-General is given a copy of the declaration "within 7 days" of the end of the period in which the underlying proceedings could be appealed, or "within 7 days after any appeal has been finalised". Section 36(7) obliges the Attorney-General to

32 Section 51(4)(b) of the New Matilda Bill.

33 See ACT Bill of Rights Consultative Committee, above n 2, 68, Human Rights

Consultation Committee, above n 2, 86 and 88 and New Matilda, above n 6, 4.

34 Neil J Young "Declarations and Other Remedies in Administrative Law" (2004)

12 Australian Journal of Administrative Law 35, 37.

35 Ainsworth v Criminal Justice Commission (1992) 175 CLR 564, 582 per Mason CJ, Dawson, Toohey, Gaudron JJ. See also Bass v Permanent Trustee Co Limited (1999) 198 CLR 334, 355-56 per Gleeson CJ. Gaudron, McHugh, Gummow, Hayne and Callinan JJ. 
give a copy of the declaration to the "Minister administering the statutory provision" which has been found to be inconsistent "as soon as reasonably practicable" after they have received it. Section 37 is drafted in language which parallels that used in the ACT. This section compels the Minister responsible for administering the inconsistent act to respond in writing to the declaration and ensure that this response is tabled before "each House of Parliament and published in the Government Gazette".

Similarly, if the New Matilda Bill were to be enacted by the Federal Parliament s 51(5) requires "a Court" to provide a copy of the declaration to the Attorney-General. The obligations which fall on the Federal AttorneyGeneral once he or she had received the declaration follow the pattern of the Territory and State laws and are contained in s 52. The Federal AttorneyGeneral is required to present a copy of the declaration within 15 sitting days of receiving it, ${ }^{36}$ while the Attorney-General's mandatory written response is to be presented to the House of Representatives "not later than 6 months" after the declaration is given to the House. ${ }^{37}$

Important consequences follow from the making of a declaration. These sections impose a duty upon the first law officer of each jurisdiction to respond to a declaration in parliament. This must be seen in light of the responsibility of ministers to parliament. In the ACT, for example, the Legislative Assembly can dismiss the executive by way of a no-confidence motion, or can pass a no-confidence motion in the Attorney-General, under the doctrines of responsible government (set out in ss 19 and 46 of the Australian Capital Territory (Self-Government) Act 1988 (Cth)). The Assembly is also capable of amending a law that has been held to be incompatible by a court. While debate continues over the efficacy of responsible government and no-confidence motions in an era when parliament is characterised by party discipline and a strong executive power, ${ }^{38}$ for the purposes of determining whether declaration mechanisms contain the requisite indicia of judicial power the important point is that the legislation stipulates that binding obligations are triggered by a declaration.

The duties imposed by the courts should also be seen in the context of the "dialogue" which the Acts (or proposed Act) seeks to implement. Human

36 Section 52(2) of the New Matilda Bill.

37 Section 52(3) of the New Matilda Bill.

38 In relation to the situation in Victoria see, for example, Robyn Eckersley and Spencer Zifcak "The Constitution and Democracy in Victoria: Westminster on Trial (2001) 36 Australian Journal of Political Science 61, 67-68. 
16 Deakin LaW ReVIEW

VOLUME 12 No 1

rights are intended to be interpreted and applied not only by the judiciary but as part of a dialogue between the judiciary, executive and legislature. ${ }^{39}$ Seen as part of this process, the duties imposed upon the Attorney-General are an important and substantive consequence of a litigant gaining a declaration of incompatibility. In the words of the ACT Bill of Rights Consultative Committee, the mechanism is a "sufficiently strong and appropriate enforcement mechanism to underpin the dialogue approach of the $A C T$ Human Rights Act" ${ }^{40}$ This is reflected in the Explanatory Statement for the Bill:

The purpose of the declaration is to draw to the attention of the Government and the Assembly a finding of incompatibility by the Court. This is an essential element in the interpretive and dialogue model upon which the Bill is based. ${ }^{41}$

The fact that the duties imposed by a declaration go beyond mere notification is also evident in the remarks made by the Victorian Attorney-General in introducing the Victorian Charter. In the second reading speech he indicated that the purpose of giving the power to make declarations to the courts "is to allow the Parliament to reconsider the provision in light of the declaration of inconsistent interpretation." ${ }^{2}$ These statements demonstrate legislative recognition that the declaration mechanisms are an (albeit novel for Australia) form of legal remedy. The declarations can be viewed in this way because they produce foreseeable and practical consequences in response to a judicial finding that a law is inconsistent with a protected human right. ${ }^{43}$

There is a further aspect of the power to make the declarations which impacts on whether it is "binding and authoritative". Implicit in discussions of judicial power, such as that of Kitto $\mathrm{J}$ in Tasmanian Breweries, quoted above is that judicial power is applied to bind the parties to the proceedings. While

39 ACT Bill of Rights Consultative Committee, above n 2, Ch 4, See esp 66-8;

Victoria, Parliamentary Debates Legislative Assembly, 4 May 2006, 1290 (Robert

Hulls), Simon Evans and Carolyn Evans, Submission to New Matilda Bill of Rights

Campaign, 17 February 2006 available at

www.newmatilda.com/admin/imagelibrary/images/eIYl15Ocb7Dy.doc ( 8

September 2006).

40 ACT Bill of Rights Consultative Committee, above n 2, 67.

41 Explanatory Statement 6, Human Rights Bill 2003 (ACT) 6.

42 Victoria, Parliamentary Debates Legislative Assembly, 4 May 2006, 1293 (Robert

Hulls).

43 By contrast, the available explanatory material about the New Matilda Bill is, of course, limited. 
we have found that obligations bestowed by the declaration mechanisms are binding, it is the Attorney-General and not the parties who are bound by these obligations. That the declarations are not binding on the parities is a relevant (albeit negative) factor in determining whether the power is judicial. However, it is not of itself decisive. On balance, we find that the power is judicial when this is weighed against other indicia that more strongly indicate an exercise of judicial power.

\section{Is a Declaration Enforceable?}

High Court decisions such as Brandy indicate that if declarations of incompatibility are unenforceable they are unlikely to be recognised as an expression of judicial power. Lacey and Wright state that satisfying this indicia might be problematic because under such a mechanism courts are unable to "enforce positive compliance with the human rights upon which the declaration would be based". ${ }^{44}$ However, these authors provide a solution to this dilemma by adopting a more expansive understanding of the enforceability requirement. They suggest that a declaration may nevertheless fall within the definition of an exercise of judicial power "provided it is conclusive of the controversy regarding inconsistency". "They recognise that this could only be the case where the factual circumstances giving rise to the incompatibility can be "merged in the judgement".

Courts already apply judicial power to issue declarations which conclude controversies in a broad range of circumstances. At common law the scope for the making of declarations is very wide. ${ }^{47}$ While a declaration will not be granted where the issue is hypothetical or where it "will produce no foreseeable consequences for the parties" 48 it may be granted where a dispute involves future rights and obligations ${ }^{49}$ or where the party seeking the

44 Wendy Lacey and David Wright, "Highlighting Inconsistency: The Declaration as a Remedy in Administrative Law and International Human Rights Standards" in Chris Finn (ed) Shaping Administrative Law for the Next Generation: Fresh Perspectives (2005) 32, 54.

45 Ibid 55. See also Bass v Permanent Trustee Co Limited (1999) 198 CLR 334, 355

per Gleeson CJ. Gaudron, McHugh, Gummow, Hayne and Callinan JJ.

46 Lacey and Wright, above n 44, 55.

47 Ainsworth v Criminal Justice Commission (1992) 175 CLR 564, 581-582 per

Mason CJ, Dawson, Toohey, Gaudron JJ.

48 Gardner v Dairy Industry Authority (NSW) (1977) 18 ALR 55, 69.

49 Commonwealth v Sterling Nicholas Duty Free Pty Ltd (1972) 126 CLR 297. 
18 Deakin LaW REVIEW

VOLUME 12 No 1

declaration may have no other cause of action. ${ }^{50}$ The case of Mellifont $v$ Attorney-General (Queensland) ${ }^{51}$ established that even the existence of practical consequences for the plaintiff is not a strict requirement for the granting of declaratory relief.

Hence, a court may grant a "bare declaration that some legal requirement has been contravened" where this "will serve to redress some or all of the harm brought about by [the] contravention". ${ }^{52}$ As High Court's rules provided: "A proceeding is not open to objection on the ground that a merely declaratory judgment or order is sought by the proceeding, and the Court may make binding declarations of right in an action or other proceeding whether any consequential relief is or could be claimed in that action or proceeding or not". ${ }^{33}$ This rule has not been replicated in the replacement High Court Rules 2004 that came into operation from 1 January 2005, but is found in the rules of other Federal and State courts. ${ }^{54}$

Other Australian laws grant a power to make declarations not unlike declarations of incompatibility. An example is the power of courts to make "Declarations of contravention" under s 1317E of the Corporations Act 2001 (Cth). Subsection (1) states: "If a Court is satisfied that a person has contravened 1 of the following provisions, it must make a declaration of contravention". It then lists a number of provisions and in a note states: "Once a declaration has been made ASIC can then seek a pecuniary penalty order (section $1317 \mathrm{G}$ ) or (in the case of a corporation/scheme civil penalty provision) a disqualification order (section 206C)". 55 Hence, as the note explains, such a declaration can be made without necessarily affecting rights and obligations.

50 Dyson v Attorney-General [1911] 1 KB 410. See also Croome v Tasmania (1997)

191 CLR 119.

51 (1991) 173 CLR 289, 303-306 per Mason CJ, Deane, Dawson, Gaudron and

McHugh JJ.

52 Truth About Motorways Pty Ltd v Macquarie Infrastructure Investment Management Ltd (2000) 200 CLR 591, 613, giving Ainsworth v Criminal Justice Commission (1992) 175 CLR 564 as an example.

53 High Court Rules 1952, Order 26, rule 19.

54 Federal Court of Australia Act 1976 (Cth) s 21; Supreme Court Act 1970 (NSW) s

75; Supreme Court Act 1986 (Vic) s 36; Supreme Court Act 1935 (SA) s 31;

Supreme Court Act 1979 (NT) s 18; Supreme Court Act 1935 (WA) s 25(6); Court

Procedure Rules 2006 (ACT) rule 2900; Supreme Court Rules 2000 (Tas) rule

103.1-2.

55 Emphasis added. 
These examples show how declarations are commonly accepted as remedies capable of putting an end to controversies before the court. Declarations of incompatibility are similar in providing a conclusion to a controversy about the incompatibility of other legislation with the protected human rights. In this, they relate to the legal question in issue as it arises out of the matter brought before the court. As in constitutional litigation, a declaration would state that the Act in question, given the circumstances in which it has been brought before the court, is inconsistent with the relevant human right spelt out in the legislation. The controversy is thereby "concluded" by the court in one of two ways. The court could determine that there is no inconsistency and so refuse to issue a declaration of incompatibility. Alternatively, the court could issue an authoritative statement (a declaration) that an inconsistency exists. As outlined above, this declaration is "enforceable" in so far as it gives rise to obligations. What is significant is that either response constitutes an answer to whether a law is incompatible with the human rights protected in the statute, and the controversy as to this is thereby concluded.

\section{Advisory Opinion?}

Thus far, we have examined whether declarations of incompatibility display the key indicia of judicial power. As noted above, this type of analysis only partially answers the question of whether the mechanisms involve the use of judicial power. To be conclusive, we now examine whether the declaration mechanisms can be distinguished from other powers that have been found not to invoke judicial power. One such case is when courts are petitioned to provide advisory opinions.

An advisory opinion involves "an abstract question, and [is] hypothetical in the sense that it was unrelated to any actual controversy between parties". ${ }^{56}$ According to the decision in Mellifont $v$ Attorney-General (Queensland) it comprises:

two critical concepts. One is the notion of an abstract question of law not involving the right or duty of any body or person; the second is the making of a declaration of law divorced or dissociated from any attempt to administer it. ${ }^{57}$

56 Mellifont v Attorney-General (Queensland) (1991) 173 CLR 289, 305 per Mason CJ, Deane, Dawson, Gaudron and McHugh JJ.

57 Ibid, 303 per Mason CJ, Deane, Dawson, Gaudron and McHugh JJ. 
20 DEAKIN LAW REVIEW

VOLUME 12 No 1

The High Court's approach to advisory opinions adopted in Mellifont was shaped by its earlier decision in In re Judiciary and Navigation Acts. ${ }^{58}$ That case made it clear that "advisory opinions" do not involve the exercise of federal judicial power. The reason for this is that such opinions do not qualify as "matters", as that term is used in ss 75 and 76 of the Australian Constitution. The majority stated:

We do not think that the word "matter" in sec 76 means a legal proceeding, but rather the subject matter for determination in a legal proceeding. In our opinion there can be no matter within the meaning of the section unless there is some immediate right, duty or liability to be established by the determination of the Court. If the matter exists, the Legislature may no doubt prescribe the means by which the determination of the Court is to be obtained, and for that purpose may, we think, adopt any existing method of legal procedure or invent a new one. ${ }^{59}$

In combination, these decisions ensure that in order to convince a court that declarations of incompatibility can be differentiated from advisory opinions it is necessary to demonstrate that such a declaration qualifies as a "matter".

It is possible to view the making of a declaration as unable to cause any change in the law in and of itself. If this view of the mechanism is adopted it would be possible to argue that making such declarations does not involve a right or duty, or an attempt to administer the law. ${ }^{60}$ If this is the case declarations might be likened to advisory opinions. This is most relevant to the New Matilda Bill where "Court" is limited in the proposed legislation to courts exercising federal jurisdiction. ${ }^{61}$ If the declaration mechanism was found to be sufficiently akin to an advisory opinion the result would be that the federal declaration mechanism would be constitutionally invalid.

If an application for a declaration of incompatibility is not held to be a matter it also creates problems for the mechanisms enacted in Victoria and the ACT, although these problems are more subtle. For instance, if making a

58 Ibid.

59 (1921) 29 CLR 257 265-266 per Knox CJ, Gavan Duffy, Powers, Rich and Starke JJ.

60 See the discussion by Geoffrey Lindell, "The Statutory Protection of Rights and Parliamentary Sovereignty: Guidance from the United Kingdom?" (2006) 17 Public Law Review 188, 204-205.

61 s 5 New Matilda Bill. 
declaration is not a "matter" the ACT Human Rights Act could not be used in cases involving federal jurisdiction. Lindell notes that this would include cases where the human rights infringement involved federal legislation. $\mathrm{He}$ also suggests that the uncertainty which exists about the extent to which the ACT Supreme Court exercises federal jurisdiction could prevent declarations from being used in cases involving legislation passed by the ACT Legislative Assembly (or even the common law) if a piece of federal legislation is the ultimate reason the ACT legislation or common law applies in the Territory. ${ }^{62}$

If the making of a declaration does not constitute a matter it may prevent cases where a declaration is made from being appealed to the High Court. ${ }^{63}$ This limitation would apply in Victoria because, as the High Court indicated in Mellifont $v$ Attorney-General (Queensland), its State appellate jurisdiction is only activated by the existence of a matter. ${ }^{64}$ This could act as a similar restriction in regard to the ACT. The High Court in Porter $v R$; Ex parte $Y e e^{65}$ accepted that the jurisdiction to hear appeals from Territory courts can be conferred upon the High Court under s 122 of the Constitution. This is reflected in s 35AA(1) of the Judiciary Act 1903 (Cth), which states that "the High Court has jurisdiction to hear and determine appeals from judgments of the Supreme Court of a Territory".

The fact that appellate jurisdiction from Territory courts is conferred on the High Court under s 122 and not under Chapter III means that this jurisdiction is not expressly limited by the need for a "matter". However, it is limited by the more general qualification that no federal court can be conferred with non-judicial power. It may also be that, although there is no express requirement for a "matter" in appeals from Territory courts, such appeals will nonetheless be held to require this. This is reflected in how the High Court has approached its State appellate jurisdiction. Hence, it is prudent, in the absence of a finding to the contrary, and given the similarities in the wording of $\mathrm{s} 73$ of the Constitution in respect of appeals from State courts and $35 \mathrm{AA}(1)$ of the Judiciary Act in respect of appeals from Territory courts, to assume that that the High Court may only determine appeals from Territory courts where a 'matter' is involved.

62 Lindell, above n 60, 207. See also James Stellios "Federal Dimension to the ACT Human Rights Act" (2005) 47 AIAL Forum 33, 34.

63 Lindell, above n 60, 207.

64 Mellifont v Attorney-General for the State of Queensland (1991) 173 CLR 289, 305 per Mason CJ, Deane, Dawson, Gaudron and McHugh JJ. See also Leslie Zines, Cowen and Zines's Federal Jurisdiction in Australia (3rd ed 2002), 20.

65 (1926) 37 CLR 432. 
This inability to approach the High Court with cases where declarations of incompatibility have been issued does not, of itself, mean that the ACT and Victorian mechanisms are invalid under the constitutional arrangements which govern those jurisdictions. Nevertheless, this inability does place a significant practical limitation on the procedure. Preventing the High Court from functioning as the final court of appeal in disputes involving declarations of incompatibility means that there would be no way to ensure that Australian jurisprudence in relation to the remedy develops consistently. This could leave the law in relation to this new remedy in an unsatisfactory state.

However, it is likely that the mechanisms do involve a "matter". Despite the decision in In Re Judiciary and Navigation Acts, the High Court has been prepared to determine questions in which declaratory relief has been sought where there has only been a tenuous link to an immediate right or duty. ${ }^{66}$ Some of these matters might even have been thought to give rise to an abstract question of law. ${ }^{67}$ In any event, the issuing of a declaration of incompatibility, as discussed above, does involve the determination of the consistency of disputed legislation with the protected human rights within the bounds of an existing conflict between parties. In this, it can be seen to meet the matter requirement and goes beyond a mere advisory opinion.

Applying for a declaration of incompatibility can also be seen to constitute a "matter" because such a request is not divorced from an attempt to administer the law. As outlined above, the ACT, Victorian and proposed federal legislation clearly indicate that declarations can only be issued in the context of a pre-existing dispute. This supports the argument that the law being administered is the law which is alleged to be incompatible with the protected human rights. To support this argument, a submission made by Evans and Evans on the New Matilda Bill drew a comparison between requesting a court to make a declaration of incompatibility and cases where the constitutional validity of a piece of legislation is contested. The submission highlighted comments in Croome v Tasmania ${ }^{68}$ that indicate that in cases where the constitutionality of a particular law is in question the law that is being administered is "the law governing the controversy about the impugned law".

66 See Croome v Tasmania (1997) 191 CLR 119, 125-6 per Brennan CJ, Dawson and Toohey JJ.

67 See Attorney-General (Vic) ex rel Dale v Commonwealth ("Pharmaceutical Benefits Case") (1945) 71 CLR 237, as discussed in Zines, above n 64, 15-16. 68 Croome v Tasmania (1997) 191 CLR 119, 126 per Brennan CJ, Dawson J and Toohey J. See also Evans and Evans, above n 39. 
The authors of the submission accepted that there is a difference between requesting that a court make a declaration of incompatibility and applying to a court for a ruling that a particular statute is constitutionally invalid. However, they saw sufficient similarity between the two processes to suggest that to make a declaration of incompatibility is to "administer a law". 69

Comparable arguments can be made to support the proposition that a request for a declaration of incompatibility involves an "immediate right or duty". This would also allow declarations of incompatibility to be distinguished from advisory opinions, and qualify as a matter. In the Evans and Evans submission on the New Matilda Bill the making of a declaration was described as being "essentially, a finding that a right is infringed by the incompatible legislation". ${ }^{70}$ Moreover, as the foregoing analysis of the operation of the various declaratory mechanisms demonstrates, one of the outstanding characteristics of the consequences which flow from a court issuing a declaration is that certain obligations (or duties) are placed on the relevant Attorney-General. ${ }^{71}$ Lindell extends the idea that these types of declarations involve "duties" by referring to cases which suggest that a duty falls upon the Crown "to seek a declaration to clarify the law". ${ }^{72}$ Evans and Evans consider this question from the perspective of the right of the person bringing the action. They highlight that the High Court has recognised that people are "entitled to know" ${ }^{73}$ whether a law is constitutionally valid. Again arguing by way of analogy, they indicate that a similar "immediate right" to know whether a human right is infringed by a particular piece of legislation underpins a request for a declaration of incompatibility. ${ }^{74}$ This ensures that any request meets the requirements for a matter.

It remains difficult to predict how this issue would be resolved should the question of the constitutional validity of declarations of incompatibility come to be adjudicated. This is because the jurisprudence surrounding the "matter" concept is complex and is characterised by "a deep division of judicial opinion". ${ }^{75}$ Mantziaris and McDonald have identified two competing

69 Evans and Evans, above n 39. See also Lindell above n 60, 205.

70 Evans and Evans, above n 39.

71 Ibid.

72 Lindell, above n 60, 205.

73 Croome v Tasmania (1997) 191 CLR 119, 138 per Gaudron, McHugh and Gummow JJ.

74 Evans and Evans, above n 39.

75 Christos Mantziaris and Leighton McDonald "Federal judicial review jurisdiction after Griffith University v Tang" (2006) 17 Public Law Review, 22. 32. See also Lindell, above n 60, 206-207. 
24 DeAKIN LAW REVIEW

VOLUME 12 No 1

interpretations of the term emerging from contemporary High Court decisions. They have labelled these the "broad" and "narrow" view of what constitutes a "matter". ${ }^{76}$ They note that under the "broad" reading of the concept a "matter" might exist even though there is "no lis inter partes or adjudication of rights". Although the judges who expound that view acknowledge that such cases are "exceptional", they would still be able to be classified as "a matter". ${ }^{77}$ Conversely, the "narrow view" requires that a matter is only established in a proceeding if the "subject matter for determination", the "right duty or liability to be established" and the "controversy" that needs to be quelled can each be specifically identified. ${ }^{78}$ In Griffiths $v$ Tang, ${ }^{79}$ a High Court majority adopted the narrow view. However, the analysis we have undertaken demonstrates that there is a strong basis for suggesting that the declaration mechanisms would still give rise to a "matter" even under the narrow view.

From a policy perspective, the use of a restrictive definition of "matter" to prevent a federal court from offering an advisory opinion is justified largely because of the dangers associated with asking those courts to declare the law on the basis of hypothetical facts. ${ }^{80}$ This underlying rationale is important because the existence (or non-existence) of a concrete fact scenario is a key criterion which differentiates advisory opinions from declaratory relief. ${ }^{81}$ As Irving puts it, the situation faced by the court in Croome illuminates this difference: a declaration was awarded in that case because the court was confronted with (and understood) the "real experience" of Mr Croome living under a legal regime which criminalised homosexual conduct. ${ }^{82}$ The point is also illustrated by the contrasting situation before Finn J in Electricity Supply Association of Australia Ltd $v$ Australian Competition and Consumer

76 Ibid., 33-34.

77 Minister for Immigration and Multicultural and Indigenous Affairs v B (2004)

219 CLR 365, 378 per Gleeson CJ and McHugh J and see Mantziaris and McDonald above $n, 75,34$.

78 Re McBain; Ex parte Australian Catholic Bishops Conference (2002) 209 CLR 372, 405-406 per Gaudron and Gummow JJ. See also Mantziaris and McDonald above $\mathrm{n} 75,33$.

79 Griffith University v Tang (2005) 221 CLR 99, 131 per Gummow, Callinan and Heydon JJ.

80 John Williams "Re-thinking advisory opinions" (1996) 7 Public Law Review 205, 206; Lindell above n 60, 206; Irving above n 25,113 and 115.

81 Bass v Permanent Trustee Co Ltd (1999) 198 CLR 334, 356-357 per Gleeson CJ, Gaudron, McHugh, Gummow, Hayne and Callinan JJ.

82 Irving, above n 25, 128 
Commission. ${ }^{83}$ His decision makes it plain that courts will be unwilling to give declaratory relief in the absence of concrete facts. ${ }^{84}$ In that case, the plaintiff approached the court seeking declarations which would have prevented the ACCC from publishing its (untested) views about an appropriate interpretation of s 71 of the Trade Practices Act 1974 (Cth) and would have endorsed the plaintiff organisation's right to publish its own (contradictory) statements on the interpretation of $\mathrm{s} 71$, some of which would have highlighted the errors in the ACCC's view. In essence the parties' representations proffered competing interpretations of "the possible impact of the implied conditions contained in $s 71 \ldots$ on electricity supply contracts with consumers". ${ }^{85}$ Finn J accepted that "unresolved questions" existed in relation to the possible existence and effect of these implied conditions. However because no actual or prospective contract existed, and neither party to the action seeking a declaration was an electricity supplier or an electricity consumer, he found that the fact scenario before him was not concrete enough to allow him to issue a declaration. ${ }^{86}$

For Young, cases such as the Electricity Supply Association demonstrate that the presence of a specifically defined set of factual circumstances is a "strict" limitation that Australian court's place on their ability to issue declaratory relief. ${ }^{87}$ However this limitation does not affect the declaration mechanisms in the Victorian Charter, ACT Human Rights Act and New Matilda Bill. As outlined above, the statutes have been drafted to ensure that declarations of this type can only be made in the context of a concrete pre-existing dispute. ${ }^{88}$ Thus when the court is asked to make declarations that legislation is incompatible with the relevant human rights legislation, parties will be approaching the court with a "real experience" rather than a hypothetical fact scenario. Hence, while the outcome of this issue in the High Court is not certain, there are strong arguments that the declaration of incompatibility mechanism can be sufficiently differentiated from an advisory opinion on the basis that it gives rise to a matter.

83 (2001) 113 FCR 230.

84 See the discussion in Young, above n 34,44-46.

85 Electricity Supply Association of Australia Ltd v Australian Competition and Consumer Commission (2001) 113 FCR 230, 233.

86 Ibid, 265.

87 Young above $n$ 34, 46.

88 Lindell makes this point in relation to declarations of incompatibility made under the ACT Human Rights Act. Lindell above n 60, 206, and as argued above, the Victorian Charter and New Matilda Bill have been drafted in a similar way. 
26 DeAkIN LaW ReVIEW

VOLUME 12 No 1

\section{E Is Making a Declaration and Exercise of Non- Judicial Power?}

The power to make a declaration of incompatibility could not be conferred on a federal court if this involved the court in the exercise of legislative power or as part of that process. ${ }^{89}$ Any suggestion that this is the case can be refuted. Courts in performing their role under the relevant human rights statute perform a fixedly judicial role. Whilst the statutes create (or anticipate creating) an obligation upon the Attorney General to table the declaration and present a response to it in parliament, ${ }^{90}$ the court itself is not involved in that process. The obligation resulting from the declaration is merely another form of the dialogue which currently exists between courts, the legislature and the executive in contexts like judicial review under the Constitution. The role of the judiciary ends with the declaration of incompatibility. The human rights statutes do not stipulate the kind of response the executive is to give. Clearly, the executive is free to respond to the declaration by informing parliament that it chooses not to amend the infringing statute. While the experience of the operation of the British declaration of incompatibility mechanism suggests that in practice it would be unusual for an executive to ignore such a declaration $^{91}$, in legal terms the power to respond legislatively remains solely with parliament.

The declaration of incompatibility mechanism can also be distinguished from laws which have been invalidated because they require the judiciary to become too involved in the activities of the legislature or the executive. This was the case in Wilson v Minister for Aboriginal and Torres Strait Islander

89 See Wilson v Minister for Aboriginal and Torres Strait Islander Affairs (1996)

189 CLR 1, 17 per Brennan CJ, Dawson, Toohey, McHugh and Gummow JJ.

90 See s 33(3) of the ACT Human Rights Act s 37 of the Victorian Charter s 52(3) of the New Matilda Bill.

91 According to the Department for Constitutional Affairs, as at 1 August 200614

Declarations of Incompatibility have been made under the Human Rights Act 1998

(UK), which have not been overturned by the House of Lords. Of these 14

declarations, 1 is subject to an appeal by the Home Office, and the relevant department is still considering the appropriate response to 2 more. Parliament has responded to the remaining 11 declarations by amending existing legislation, enacting new legislation or proposing to enact new legislation. See Department for Constitutional Affairs "People's Rights, Human Rights, Frequently Asked Questions" www.dca.gov.uk/peoples-rights/human-rights/faqs.htm (27 March 2007). See also Francesca Klug and Keir Starmer, "Standing Back from the Human Rights Act: How Effective is it Five Years On?" [2005] Public Law 716. 
Affairs. ${ }^{92}$ In that case it was held that the impugned law put the independence of the judiciary at risk because it appointed a judge as the head of an inquiry process. The majority judges provided a list of factors which can be used as a guide to determine whether public confidence in the judiciary was impaired when judges performed non-judicial tasks. ${ }^{93}$ When these factors are applied to the situation of a judge who has been asked to make a declaration of incompatibility the stark differences between the two situations can be observed. In Wilson it was held that the impugned legislation put the judge in that position. More importantly one of the major problems with the position of the judge in Wilson was the lack of a requirement that the judge act independently. ${ }^{94}$ By contrast, independence from the executive (and legislature) is integral to a power given to a court to declare that a particular law passed by parliament is incompatible or inconsistent with the relevant human rights legislation. Furthermore, the report in Wilson required the judge in question to make overtly "political decisions" about various aspects of the land which was the subject of the report. ${ }^{95}$ In comparison, the choice whether to issue a declaration of incompatibility is a legal decision, as a judge will be asked to interpret statutes and determine whether they can be read harmoniously together. Finally, it is worth remembering that public confidence in the British judiciary has not collapsed because those judges have been given the power to make similar declarations. Even allowing for differences in constitutional structure, this can be seen as an indication that making declarations is not so completely antithetical to the typical judicial function that making them endangers the reputation of the judiciary.

\section{IN The Alternative: What If Judicial POWER is NOT INVOLVED?}

As outlined above there are strong arguments to suggest that declarations of incompatibility involve the exercise of judicial power. However, as also acknowledged, courts determine the existence of judicial power in an incremental fashion, and the concept itself has proved incapable of being

92 (1996) 189 CLR 1.

93 Ibid, 17-20 per Brennan CJ, Dawson, Toohey, McHugh and Gummow JJ. See also Gerard Carney "Wilson and Kable: The Doctrine of Incompatibility- An Alternative to the Separation of Powers" (1997) 13 Queensland University of Technology Law Journal 175,180-181.

94 Wilson v Minister for Aboriginal and Torres Strait Islander Affairs (1996) 189 CLR 1, 18-19 per Brennan CJ, Dawson, Toohey, McHugh and Gummow JJ. 95 Ibid, 19 per Brennan CJ, Dawson, Toohey, McHugh and Gummow JJ. 
28 DEAKIN LAW REVIEW

VOLUME 12 No 1

given a fixed meaning. This means that it is possible that a court asked to consider these questions might weigh the indicia differently and conclude that making declarations is not an exercise of judicial power. Accordingly, we consider whether such mechanisms would be constitutionally valid if this were the case.

\section{A New Matilda Bill}

If declarations of incompatibility are held not to involve the exercise of judicial power then the mechanism in the New Matilda Bill will be invalid. The Boilermakers" Case recognised that the Australian Constitution institutes a strict separation of powers at federal level. ${ }^{96}$ This structure means that courts established under Chapter III are the sole repositories of the "judicial power of the Commonwealth". 97

\section{B Victorian Charter}

Under the Constitution Act 1975 (Vic) the Victorian parliament has plenary power, with s 16 specifying that the "Parliament shall have power to make laws in and for Victoria in all cases whatsoever". More significantly, it has been held that the Constitution Act, like the constitutions of others States, ${ }^{98}$ does not incorporate a doctrine of separation of powers. ${ }^{99}$ This means that, but for two caveats, the question of whether the declaration mechanism in the Victorian Charter requires judicial power is irrelevant to determining whether the mechanism is constitutionally valid. Thus, even if the making of such a declaration is not an exercise of judicial power, it would still be valid under the Victorian Constitution.

96R v Kirby; Ex parte Boilermakers' Society of Australia (Boilermakers' Case) (1956) 94 CLR 254. See also Fiona Wheeler, "Due Process, Judicial Power and Chapter III in the New High Court" (2004) 32 Federal Law Review 205, 207-209. 97 Australian Constitution s 71.

98 See Kable v Director of Public Prosecutions (NSW) (1996) 189 CLR 51, Clyne v East (1967) 68 SR(NSW) 385 and Building Construction Employees and Builders' Labourers Federation of New South Wales v Minister for Industrial Relations (1986) 7 NSWLR 372 as to the Constitution Act 1902 (NSW).

99 See City of Collingwood v State of Victoria [No 2][1994] 1 VR 652, 662-663 per Brooking J. See also Dan Meagher "Should the Victorian Constitution be Reformed to Strengthen the Separation of Judicial Power" (2000) 2 Constitutional Law and Policy Review 63. 
The two caveats are as follows. First, if a declaration is not an exercise of judicial power then appeals to the High Court from the Victorian Supreme Court would be restricted in the same way as would occur if the declaration mechanism is found not meet the requirements of a "matter". As discussed earlier, this would restrict the practical utility of the declaration mechanism. ${ }^{100}$

Second, following the decision in Kable v Director of Public Prosecutions $(N S W),{ }^{101}$ the Victorian Supreme Court cannot be vested with jurisdiction by the Victorian Parliament that was "incompatible" with the exercise of federal judicial power by that Court. Kable placed that restriction on the NSW Parliament and Supreme Court even though it was accepted that the Constitution Act 1902 (NSW) does not itself entrench a separation of judicial power. The limitation derives from the High Court's recognition that the State courts are an integrated part of the Australian judicial system and can be required to exercise federal judicial power. ${ }^{102}$ Moreover, while there were suggestions in Kable that the decision only applied to cases where the State court was actually exercising federal jurisdiction, ${ }^{103}$ the High Court has subsequently made it clear that the decision operates generally to guarantee the impartiality of State courts. ${ }^{104}$

The implications of the Kable decision have been described as controversial $^{105}$ and they now constitute a constitutional principle that prevents State parliaments from passing laws which would result in

100 See the discussion of the "matter" concept above.

101 (1996) 189 CLR 51.

102 Kable v Director of Public Prosecutions (NSW) (1996) 189 CLR 51,101 per Gaudron J and 114 per McHugh J.

103 Kable v Director of Public Prosecutions (NSW) (1996) 189 CLR 51, 99 per

Toohey J. See also Leslie Zines above n 64, 244.

104 See Ebner v Official Trustee in Bankruptcy (2000) 205 CLR 337, 363 per

Gaudron $\mathrm{J}$ and the subsequent endorsement of her comments in North Australian Aboriginal Legal Aid Service Inc v Bradley (2004) 218 CLR 146, 163 per McHugh, Gummow, Kirby, Hayne, Callinan and Heydon JJ. This passage of the judgment is more fully quoted below. See also Stephen Donaghue "Judicial Independence: Bradley, Fardon and Baker"(Paper presented at the Gilbert + Tobin Centre of Public Law 2005 Constitutional Law Conference, Sydney, 18 February 2005), 3. Paper available at www.gtcentre.unsw.edu.au/publications/papers/docs/2005/5_StephenDonaghue.pdf (accessed 20 March 2007).

105 Fiona Wheeler "The Kable Doctrine and State Legislative Power Over State Courts" (2005) 20(2) Australasian Parliamentary Review 1516. 
30 DeAKIN LAW ReVIEW

VOLUME 12 No 1

"institutional integrity of a court ... [being] distorted". ${ }^{106}$ In the most recent discussion of Kable in Forge $v$ Australian Securities and Investments Commission ${ }^{107}$ the High Court indicated that "the institutional integrity of a court is distorted... [when] the body no longer exhibits in some relevant respect those defining characteristics which mark a court apart from other decision-making bodies". Following Forge, if Kable is applied to the declaration mechanism in the Victorian Charter the question will be: does making such a declaration mean that the Supreme Court is no longer acting as a court?

Despite the consideration of Kable in Forge it remains unclear precisely what characteristics of a court are protected by the Kable doctrine and cannot be altered by State legislatures. ${ }^{108}$ Some guidance might be drawn from the facts of the decision in Kable. Kable concerned the Community Protection Act 1994 (NSW), which empowered the NSW Supreme Court to make "preventive detention orders". This enabled the Supreme Court to order the imprisonment of a person although that person had not been found guilty of a criminal offence. The Act only applied to one person, s 3(3) providing that: "This Act authorises the making of a detention order against Gregory Wayne Kable and does not authorise the making of a detention order against any other person." A 4:3 majority of the High Court held, in the words of McHugh J, that "the Act is invalid because it purports to vest functions in the Supreme Court of New South Wales that are incompatible with the exercise of the judicial power of the Commonwealth by the Supreme Court of that State". 109

The courts have not set down a definitive list of functions which are incompatible with the exercise of judicial power. However, it is clear that an incompatible function would be one which prevents judges from exercising a non-judicial task that impairs the ability of that judge (or the judiciary as a whole) to exercise their judicial duties with integrity. A function may also be incompatible if it damages public confidence in the capacity of an individual judge or the judiciary as a whole to perform their functions with

106 Forge v Australian Securities and Investments Commission [2006] HCA 44, para 63 per Gummow, Hayne and Crennan JJ. See also Wheeler, above n 105, 21- 22.

107 Forge v Australian Securities and Investments Commission [2006] HCA 44, para 63 per Gummow, Hayne and Crennan JJ.

108 See Forge v Australian Securities and Investments Commission [2006] HCA 44, para 64 per Gummow, Hayne and Crennan JJ.

109 Kable v Director of Public Prosecutions (NSW) (1996) 189 CLR 51, 109. 
"integrity" ${ }^{110}$ It was this aspect of the "incompatibility doctrine" which was applied in Wilson $v$ Minister for Aboriginal and Torres Strait Islander Affairs. ${ }^{111}$ As discussed above in that case the High Court held, with Kirby $\mathbf{J}$ dissenting, that the appointment of Justice Jane Mathews of the Federal Court to prepare a report for the Commonwealth Minister for Aboriginal and Torres Strait Islander Affairs under s 10 of the Aboriginal and Torres Strait Islander Heritage Protection Act 1984 (Cth) was invalid. Brennan CJ, and Dawson, Toohey, McHugh and Gummow JJ found ${ }^{112}$ that the function of the author of a report under s 10 was not an independent one, but a "position equivalent to that of a ministerial adviser" which "places the judge firmly in the echelons of administration, liable to removal by the minister before the report is made and shorn of the usual judicial protections". This breached the incompatibility doctrine in that it undermined "public confidence in the integrity of the judiciary as an institution or in the capacity of the individual judge to perform his or her judicial functions with integrity". ${ }^{113}$

In our earlier discussion of Wilson we advanced the view that the declaration mechanism is not itself incompatible with a courts judicial role. Indeed we argued that making such a declaration requires courts to independently assess the legislation which is held to be incompatible. Therefore, it seems unlikely that an argument would succeed that public confidence in the integrity of the judiciary is lessened because declarations impair judicial independence.

Further guidance on the extent to which the Kable principle prevents the Victorian Parliament from empowering courts with a non-judicial declaration mechanism can be gleaned from Fardon $v$ Attorney-General for the State of Queensland. ${ }^{114}$ It indicates that the High Court will be cautious in applying Kable. In Fardon, the High Court rejected an attack on the Dangerous Prisoners (Sexual Offenders) Act 2003 (Qld). It was argued that the Act breached Chapter III of the Constitution by involving the Supreme Court of Queensland in the process of deciding whether prisoners who had been convicted of serious sexual offences should be the subject of continuing detention orders on the ground that they represented a serious danger to the community. The Court held that the Act did not confer a function on the Supreme Court that was incompatible with the Court's position as a potential

110 See for example Grollo v Palmer (1995)184 CLR 348, 364 per Brennan CJ, Deane, Dawson and Toohey JJ.

111 (1996) 189 CLR 1.

112 Ibid 18-19.

113 Ibid 16, 18-19.

114 (2004) 210 ALR 50. 
32 DEAKIN LAW REVIEW

VOLUME 12 No 1

repository of federal jurisdiction. The grounds upon which Kable was distinguished included that while Kable had concerned a law directed at only one person, the Queensland statute was a law of general application. The decision established, as McHugh $\mathrm{J}$ remarked, that "Kable is a decision of very limited application". ${ }^{115}$

However limited the Kable principle might now be, it is clear that it could still be used to prevent parliaments from bestowing powers on State courts which compromise the "institutional integrity" of those courts, such as if the power damaged their ability to be, or reputation for being, impartial. ${ }^{116}$ Indeed McHugh J said it was precisely because the Queensland statute in Fardon did not have this effect that the argument based on the Kable principle could not succeed. ${ }^{117}$ Similarly, Gleeson CJ examined the powers given to the Supreme Court of Queensland and could not find anything in the Act "to suggest that the Supreme Court is to act as a mere instrument of government policy". ${ }^{118}$ Callinan and Heydon JJ also affirmed the rationale of Kable that a State courts' "integrity and independence as a court ...[is] not compromised" and the court remains able "to undertake a genuine adjudicative process". A key reason why the legislation in Fardon did not infringe the principle was that it contained processes which bore "the hallmarks of traditional judicial forms and procedure". ${ }^{119}$

If this form of non-judicial power in Fardon can co-exist compatibly with the judicial power exercised by State Courts, then a non-judicial power to make declarations of inconsistent interpretation ought to survive any application of the Kable principle. Indeed, in our foregoing analysis we have pointed out the many parallels which can be drawn between making declarations and other tasks which courts have traditionally carried out. These similarities make it very unlikely that a declaration of inconsistent interpretation would be invalidated by the Kable principle as it is currently applied and understood.

If the declaration mechanism in the Victorian Charter can be shown to damage the capacity of the Victorian Supreme Court to act independently and impartially, the Kable principle (in the wake of Forge) might be used to

115 Fardon v Attorney-General (Queensland) (2004) 210 ALR 50, 65.

116 See in relation to the situation post Fardon but pre Forge Peter Johnston "State

Courts and Chapter III of the Constitution: Is Kable's Case Still Relevant ?" (2005)

32 University of Western Australia Law Review 211, 230-232.

117 Fardon v Attorney-General (Queensland) (2004) 210 ALR 50, 62 per McHugh J

118 Ibid, 57 per Gleeson CJ.

119 Ibid, 110 per Callinan and Heydon JJ. 
invalidate it. However, as we have demonstrated, the declaration mechanism merely asks the Supreme Court to make an assessment, based on legal criteria, of whether a particular piece of Victorian legislation is inconsistent with a human right set out in the Victorian Charter. As we have also indicated in our discussion contrasting the power to make declarations and the situation in Wilson, such an assessment, of its very nature, will require the Court to act independently of the executive and legislature that initiated and then passed the contested legislation. Finally, the similarities between making declarations of inconsistent interpretation and other judicial processes suggest that they will not have a detrimental impact on the impartiality (real or apparent) of the Court.

\section{ACT Human Rights Act \\ 1 Is there a separation of powers doctrine in the Australian Capital Territory (Self-Government) Act?}

The powers of the ACT Legislative Assembly are set out in s 22 of the Australian Capital Territory (Self-Government) Act 1988 (Cth). This enables the Assembly "to make laws for the peace, order and good government of the Territory". These words confer plenary legislative power upon the Assembly. ${ }^{120}$ An Act of the ACT Legislative Assembly will be valid unless a separate limitation can be found either in other sections of, or by implication from, the Australian Capital Territory (Self-Government) Act. A possible implication from the Act is that it entrenches a separation of judicial power. If the declaration of incompatibility mechanism were held to involve an exercise of non-judicial power, this might provide a basis for holding the mechanism invalid.

However, in De Domenico v Marshall, ${ }^{121}$ Miles CJ of the ACT Supreme Court stated:

It must be recognized that, in the governmental structure of a Territory of the Commonwealth, there is no requirement of a strict

120 Any suggestion to the contrary was rejected by the High Court in an analogous context in Union Steamship Co of Australia Pty Ltd v King (1988) 166 CLR 1. In that case, a unanimous Court held that a similar grant of power to a State confers, rather than limits, parliamentary sovereignty.

121 (1999) 142 ACTR 1, 6. 
34 DEAKIN LAW REVIEW

VOLUME 12 No 1

division between judicial power on the one hand and executive or administrative power on the other hand. In contrast to the division between the judicial and executive power of the Commonwealth, created and recognised by the Constitution, particularly Chapter III, there appears to be no fetter on the exercise of judicial power by executive or administrative bodies created by or under legislation of the Commonwealth Parliament pursuant to the power to make laws for a Territory pursuant to $\mathrm{s} 122$ of the Constitution.

While this question has not been authoritatively determined, this dicta is likely to be correct. It is consistent with the approach taken in Victoria and other States. In the case of NSW, this was confirmed by the High Court in Kable v Director of Public Prosecutions (NSW). ${ }^{122}$ No separation of judicial power was found in that case despite the Constitution (Amendment) Act 1992 (NSW) amending the NSW Constitution to provide for judicial independence and security of tenure. It is unlikely that a doctrine of the separation of judicial power would be implied from the Australian Capital Territory (Self-Government) Act.

\section{Does the separation of powers doctrine in Chapter III of the Constitution apply?}

The High Court accepted in Re Governor, Goulburn Correctional Centre; Ex parte Eastman $^{123}$ that the Australian Capital Territory (Self-Government) Act was enacted by the Commonwealth Parliament under its power to "make laws for the government" of the Territories under s 122 of the Constitution. Unlike the powers listed in s 51 of the Constitution, s 122 is not expressed to be "subject to this Constitution". The power conferred by s 122 is generally assumed to be a plenary power equivalent to the "peace, order and good government" powers assigned to the States by their own Constitution Acts.

However, as Gummow J explained in Newcrest Mining (WA) Ltd $v$ Commonwealth, ${ }^{124}$ the description of a power as "plenary" does not necessarily mean that it is subject to no limitations. It has been held, for example, that the Commonwealth's exclusive power to levy duties of excise under s 90 of the Constitution excludes the self-governing Territories just as

122 (1996) 189 CLR 51. See the discussion of this case above.

123 (1999) 200 CLR 322.

124(1997) 190 CLR 513, 604-5. 
it excludes the States. ${ }^{125}$ On the other hand, there is no clear authority on the extent to which the power in $\mathrm{s} 122$ is limited by other guarantees, such as that of freedom of religion in s 116 of the Constitution. It has also been unclear whether laws passed by the ACT Legislative Assembly under the Australian Capital Territory (Self-Government) Act are subject to limitations arising from the separation of judicial power under the Constitution.

In Spratt v Hermes, Kitto and Taylor JJ accepted the view that the whole of Chapter III of the Constitution had no application to judicial power conferred by laws made under s $122 .{ }^{126}$ Other members of the Court were more cautious. Barwick CJ and Menzies J , while holding that s 72 was inapplicable to judicial appointments in the Territories, denied that this meant that Chapter III as a whole had no application. ${ }^{127}$ This tension has not yet been fully resolved by the High Court, making it difficult to determine which parts of the Constitution, and especially of Chapter III, apply to the Territories.

The finding in Spratt $v$ Hermes, that the requirements of s 72 were not applicable to the appointment of an ACT magistrate, was reaffirmed in Capital TV and Appliances Pty Ltd v Falconer, ${ }^{128}$ and extended to the appointment of judges of the ACT Supreme Court. The same result was reached in Re Governor, Goulburn Correctional Centre; Ex parte Eastman. ${ }^{129}$

In Kruger v Commonwealth, ${ }^{130}$ Dawson J, with whom McHugh J agreed, held that "[c]ourts created under s 122 are not federal courts", and accordingly that the doctrine of separate and independent judicial power "has no application in the territories". Brennan CJ applied "the accepted doctrine" to that effect. ${ }^{131}$ On the other hand Toohey, Gaudron and Gummow JJ all expressed support for the opposite view, though none of them finally decided the issue. ${ }^{132}$ The Court in Kruger was thus evenly divided on the issue. Other more recent decisions of the High Court have confirmed the insistence of Barwick CJ in Spratt $v$ Hermes that the issue must be fragmented: that is, that not all

125 Capital Duplicators Pty Ltd v Australian Capital Territory (No 1) (1992) 177 CLR 248.

126 (1965) 114 CLR 226, 251 per Kitto J and 260 per Taylor J

127 (1965) 114 CLR 226, 245 per Barwick CJ and 269-270 per Menzies J.

128 (1971) 125 CLR 591.

129 (1999) 200 CLR 322.

130 (1997) 190 CLR 1, 62.

131 Ibid, 44.

132 Ibid, 84 per Toohey J, 109 per Gaudron J and 162 per Gummow JJ. 
36 DEAKIN LAW REVIEW

VOLUME 12 No 1

provisions in Chapter III can be put aside as not "applicable to the territories". ${ }^{133}$ It is unlikely that Chapter III of the Australian Constitution imports a separation of powers doctrine into the constitutional arrangements of the ACT.

\section{$3 \quad$ Does Kable apply to ACT Courts?}

The High Court examined the applicability of Kable to the Territories in North Australian Aboriginal Legal Aid Service Inc $v$ Bradley. ${ }^{134}$ Not surprisingly, the High Court was concerned to ensure that Territory courts are a functioning part of an integrated Australian judicial system. In that case, the Court dealt with the notion, expressed by Gaudron $\mathrm{J}$ in Ebner $v$ Official Trustee in Bankruptcy, ${ }^{135}$ that:

Impartiality and the appearance of impartiality are necessary for the maintenance of public confidence in the judicial system. Because State courts are part of the Australian judicial system created by Ch III of the Constitution and may be invested with the judicial power of the Commonwealth, the Constitution also requires, in accordance with Kable $v$ Director of Public Prosecutions (NSW), that, for the maintenance of public confidence, they be constituted by persons who are impartial and who appear to be impartial even when exercising non-federal jurisdiction. And as courts created pursuant to s 122 of the Constitution may also be invested with the judicial power of the Commonwealth, it should now be recognised, consistently with the decision in Kable, that the Constitution also requires that those courts be constituted by persons who are impartial and who appear to be impartial.

After quoting this passage, McHugh, Gummow, Kirby, Hayne, Callinan and Heydon $\mathrm{JJ}^{136}$ accepted that, like their State court counterparts, Territory courts may be invested with federal judicial power. Thus Territory courts also need to "be and appear to be" fitting repositories of this power, and this "requires discernment of the relevant minimum characteristic of an

133 Spratt v Hermes (1965) 114 CLR 226, 245. Compare Northern Territory v GPAO (1999) 196 CLR 553 and Re Governor, Goulburn Correctional Centre; Ex parte Eastman (1999) 200 CLR 322.

134 (2004) 218 CLR 146.

135 (2000) 205 CLR 337, 363.

136 (2004) 218 CLR 146, 163. 
independent and impartial tribunal exercising the jurisdiction of the courts over which the Chief Magistrate presides". ${ }^{137}$ The Court concluded by acknowledging that it is impossible to provide definitive guidance as to what this minimum might be. However, they endorsed McHugh J's comments in Kable that it would be unacceptable if a Territory court was given:

functions or duties might lead ordinary reasonable members of the public to conclude that the [Territory] court as an institution was not free of government influence in administering the judicial functions invested in the court. ${ }^{138}$

In the final analysis, the territory law in question (the Magistrates Act (NT)) was valid because it did not make the:

magistracy of the territory or the office of the Chief Magistrate inappropriately dependent on the legislature or executive of the territory in a way incompatible with requirements of independence and impartiality. It does not compromise or jeopardise the integrity of the territory magistracy or the judicial system. Nor is it apt to lead reasonable and informed members of the public to conclude that the magistracy of the territory was not free from the influence of the other branches of government in exercising their judicial function. To the contrary, the legislative requirement of continued attention by the executive of the territory to the preservation of adequate remuneration of the magistrates, including the Chief Magistrate, is apt to defend the interests of judicial independence and impartiality which inform the legislation. ${ }^{139}$

The decision of the High Court in North Australian Aboriginal Legal Aid Service Inc $v$ Bradley is significant because it establishes that Territory courts that may be vested with federal jurisdiction are subject to the Kable limitation. ${ }^{140}$ Accordingly, if the ACT mechanism is held to be an exercise of non-judicial power it is possible that it might be invalid due to the application of Kable. However, it is probable that the current High Court would apply it

137 Ibid.

138 Ibid, 163. The comments referred to can be found in Kable v Director of Public Prosecutions (NSW) (1996) 189 CLR 51, 119.

139 Ibid, 172.

140 This finding contradicted what many had previously thought to be the case. See for example David Mossop, "The Judicial Power of the Australian Capital Territory" (1999) 27 Federal Law Review 19, 29. 
to the ACT courts as it was applied in Fardon and in Forge; that is to say it is likely not to operate in this case but only in exceptional circumstances that give rise to a clear incompatibility, or where the independence or impartiality of the ACT Supreme Court is threatened.

\section{CONCLUSION}

The ACT Human Rights Act, Victorian Charter and New Matilda Bill present a new compromise between the protection of human rights and the maintenance of parliamentary sovereignty. The constitutional validity of the declaration of incompatibility mechanisms in each must be seen in the light of what is still a developing and uncertain jurisprudence on the scope and definition of judicial power. Nevertheless, the stronger view is that the mechanisms are valid. This is based upon our conclusion that a declaration of incompatibility is an exercise of judicial power. If it is not, such a mechanism enacted at the federal level would be unconstitutional, while the mechanisms enacted in the ACT and Victoria will still likely be valid.

From a normative perspective, there are further good reasons to view the mechanism as an exercise of judicial power. As the experience of like jurisdictions makes clear, the existence of such a mechanism in the UK and New Zealand has proved beneficial in the protection of individual liberties while still allowing courts to fulfil their traditional function. The mechanism may be novel, but it has not there been seen as unjudicial.

This is consistent with one of the central rationales for the separation of judicial power under the Australian Constitution. The doctrine has an important role not just in securing judicial independence but in protecting individual liberties through the dispersal of power and the application of the rule of law. This has been acknowledged in the High Court. In Street $v$ Queensland Bar Association, ${ }^{141}$ for example, Deane $\mathrm{J}$ in the context of listing a number of rights contained in the Constitution commented: "The most important of them is the guarantee that the citizen can be subjected to the exercise of Commonwealth judicial power only by the "courts" designated by Ch III (s 71)". Similarly, in Tracey; Ex parte Ryan ${ }^{142}$ he said that the separation of federal judicial power is "the Constitution's only general guarantee of due process". It would be ironic if a separation of judicial power

141 (1989) 168 CLR 461, 521.

142 (1989) 166 CLR 518, 580. 
designed to protect the community from the misuse of public power and to protect their individual liberties were applied in a narrow and legalistic fashion to strike down a mechanism directed to the same objective. 
40 Deakin Law Review Volume 12 No 1 